\title{
Woody forest products utilization and rural area transformation in Eastern Uganda: a case of Nabitende Township, Iganga district
}

\author{
Otieno, A. Charles \\ Department of Geography and Social Development School of Humanities and Social Sciences \\ Jaramogi Oginga Odinga University of Science \& Technology P.O.Box 210-40601, Bondo. (Kenya)
}

\begin{abstract}
Exploitation of woody forest products on private land has superseded their regeneration hence unsustainable despite the many benefits accrued from the activity in eastern Uganda. A study of 253 households from Nabitende Township, a timber collecting centre with an agglomeration of wood processing workshops in Iganga district revealed that; the major woody forest products exploitation activities at Nabitende Township were furniture making (75\%) and pit sawing/timber processing (59.3\%); a correlation analysis of the perception of both wood processors and non-wood processors on the factors favouring wood works at the township showed that $r=0.25$ at 0.05 level of significance which was a slight relationship but the artisan skills was generally agreed as the major factor(85.8\%); the most preferred timber species was Maesopsis eminii (86.2\%) and Milicia excelca (86.2\%) while the least were fruit trees, Mangifera indica (51.8\%) and Artocapus heterophylus (59.7\%); the woody forest products were sourced from the neighbourhood of the township such as Kaliro district, Buyende district, Namutumba district and Nawandala sub-county;Iganga town was the most significant market for wood products from Nabitende township at $\left(\chi^{2}=1.7<9.21\right.$ at $\left.d f=2\right)$ compared to other markets. This could be attributed to the place being a collecting centre in Eastern Uganda. Other very significant markets were Busia, Mbale, Kampala city, Kumi, Juba city, Malaba and Jinja town all at $\left(\chi^{2}<9.21\right.$ at $d f=2)$; despite the statistically negative correlation interviews and observation agree on the fact that forest wood products exploitation has transformed the hither to rural environment. The researchers therefore recommended that both forest and environmental officers should sensitize the artisans on sustainable utilization of woody forest products especially discouraging wasteful machines; the local authorities to enforce the labour laws deterring child labour and early marriages to give room for education so as to sustain the transformation so far achieved.
\end{abstract}

Key words: furniture making, non-wood processors, pit sawing, wood processors, small scale industries, timber species

\section{Introduction}

Wood forest products exploitation leading to deforestation is manifested in the reduction of forest estate in Uganda. It was estimated that in 1890 approximately $45 \%$ (about 10.8 million ha (108,000 $\mathrm{km} 2)$ of Uganda was forested and woodlands representing. Uganda is estimated to be losing about 50,000 (0.8\%) of forestlands annually most of which occurs in woodlands outside the protected areas (FAO (1997) cited by National Environment Management Authority (NEMA),2001). The estate has reduced to 3.6 million hectares at a rate of $1.9 \%$.This deforestation could be apportioned as private lands at nearly 1.3 million hectares while the gazatted 91,000 hectares (NFA (2008) cited by Obua et al, 2010).

Much (70\%) of the forested area is on private land. The rest being held in trust by government for the citizen of Uganda, $15 \%$ in National Parks and Wildlife Reserves managed by Uganda Wildlife Authority(UWA). The districts manage a small portion (5000 ha) of Local Forest Reserves (Republic of Uganda, 2002).According to National Forestry Authority (NFA) 2005 gazatted/central forest reserves are managed by NFA viz. 506 reserves in the country. NFA manages the reserves in partnership with the private sector such as companies, firms, non-governmental organizations; community organizations, and individuals, the central government and local government in accordance with the National Forestry and Tree Planting Act 2003 (The Republic of Uganda, 2003). The reserves given the protection are not highly deforested compared to forests in the private lands.

Many writers have it that woody forest products exploitation has a linkage with population growth especially in the tropical developing countries (Whitmore \& Sayer, 1994; De Blij 1988). Simon (1981) attributes this exploitation to the nature of man as a resource utilizing animal manifested in everything he uses ranging from food items to objects he fabricates to make a comfortable living. Through the urge for comfort he transforms his surroundings. Some authors claimed excessive commercial logging rose 15 times since 1950s with an increase in newsprints and other paper products. This also extended in timber ad charcoal consumptions in growing urban areas in developing countries (De Blij, 1988; D'Silva \& Appanah 1993; Gachanja, 2000; Otieno \& Buyinza, 2010). The saw mill at Nabitende was established by Bernard and William in 1949. It used 
steam boilers through fuel wood. The timber produced mainly of Milicia excelca species was for export. This therefore conformed to the excessive woody forest product consumption in the West besides Japan.

The Uganda Forestry Policy 2001 provides for the development of forest-product processing industries with regard to both pit sawing and saw milling. The policy on its fourth statement aims at promoting a modern, competitive, efficient and well-regulated forest product processing industry in the private sector (Republic of Uganda 2001cited by Odokonyero, 2005).The reality on ground is inefficiency of the machines applied locally which lead to excessive wastes in form of saw dusts a manifestation of lack of regulations in the sector. The case study area has a number of locally assembled machines given the capital such as; morticing machines, wood lathe and table/circular saws which were wasteful.

Uganda is naturally endowed with a variety of tree species in her natural forests besides the recent developments in the establishment of exotic tree species such as pines and eucalyptus (Sawlog Production Grant Scheme, 2007 cited by Odokonyero, 2005).In Eastern Uganda the following species were commonly used as per this research; Muvule(Milicia excelca), Mukoko (Ficus platyphylla), Muyembe(Mangifera indica), Fenhe(Artocapus heterophylus), Mukunyu(Ficus sur), Kilitunsi (Eucalyptus grandis), Musizi (Maesopsis eminii), Musita(Alizia coriaria), Kabalira (Ficus mucuso), Mugaire (Piliostigma thonningii),Muziru (Pseudosndias microcarps), Musambya (Markhamia lutea)and Nongo (Albizia grandibracteata).

The researchers had the following specific objectives in carrying out this research; to assess the factors favouring woody forest products exploitation at Nabitende Township, Eastern Uganda; to establish the woody forest resources used at Nabitende Township, Eastern Uganda; and to assess the contribution of woody forest product exploitation on the transformation of Nabitende village into a township in Eastern Uganda.

\section{Description Of The Area Of Study}

Nabitende township is within Nambale sub-county, Kigulu county, Iganga district. The district is in eastern Uganda at latitudes $1^{0} 00^{\prime}-1^{0} 06^{\prime} \mathrm{N}$ and longitudes $33^{0} 51^{\prime} \mathrm{E}-33^{0} 12^{\prime} \mathrm{E}$. It is relatively located as follows; Kaliro district to its north, Namutumba district to the north east, Bugiri district to the east, Mayuge district to the south, Jinja to the south west and Luuka district to the west. It is approximately $102 \mathrm{~km}$ from Kampala; the capital city of Uganda (http.//www.fao.org, 2007) . The Township where the research was carried out was about $27 \mathrm{kms}$ north of Iganga municipality and about $5 \mathrm{~km}$ south of Kaliro town along Iganga/Kaliro road.

The district has a mean annual rainfall of about $1250 \mathrm{~mm}$ received within 100-130 days per annum in reflection of the Equatorial troughs viz. April-May and September-November. The vegetation is predominantly forest/savannah mosaic, which is a mixture of isolated forest remnants and colonizing savannah trees integrated with grasses and shrubs (IDFA, 2013; Ibid, 2007). The vegetation combination could be attributed to clearing of the original forests for farming, grazing, timber, fuel and other human activities. The climate and vegetation therefore favours the existence of a variety of tree species exploited and collected at Nabitende Township, eastern Uganda.

\section{Materials And Methods}

This was a case study conducted through a cross-sectional research design. It was to assess the contribution of exploitation of forest wood products towards the transformation of rural areas in Eastern Uganda. The design enabled the researchers to obtain information that described existing phenomena with respect to one or more variables (Mugenda \& Mugenda, 2003). Given its nature as viewed by many authors including the researchers, triangulation was used (Gay et al, 2009; Bailey, 2007; Amin, 2005; Morse \& Richards, 2002; Nachmias \& Nachmias, 1987). A total of 253 respondents participated randomly selected from the stratified households in terms of parishes within Nabitende Township Eastern Uganda. The triangulation of sampling techniques viz. probability and non-probability sampling techniques were concurrently used (Bailey, 2007; Amin, 2005). The techniques applied for both sampling and data collection were; stratified sampling; snowballing, purposive and convenience techniques.

The researchers used; questionnaires, interviews, observation, and document analysis as the main tools for collecting data. They were mainly concerned with views and perceptions of the respondents. Most authors including the researchers agree that such information could be best collected using the given tools (Bell, 1999; Cauvery et al, 2007). The percentage distribution technique was used to show the particular frequencies of respondents preferring a particular alternative to give the face value implications of activities, species of timbers used, significance of forest wood products utilization, and perceptions. Statistical Package for the Social Sciences Version 10 was used given the number of respondents and carrying out cross tabulations which could not be done either manually or using Excel (Fisher, 2007; Freankel \& Wallen, 2008). Non-parametrical statistical techniques such aschi-square tests $\left(\chi^{2}\right.$ test) and Spearman's Rank Correlation were used to establish both the statistic value of the residents' views on market for wood productsandcorrelation analysis of the perceptions of wood and non-wood processors on factors favouring woody forest resources exploitation. The 
researchers also correlatedthe perceptions of wood and non-wood processors on contribution of exploitation of forest wood products on transformation of Nabitende Township.

\section{Results And Discussions}

This section presents the results in a tabular form and then gives a discussion thereafter. It was determined by the objectives of the study but proceeded by the demographic and socio-economic characteristics of the household respondent as in Table: 1 .

Table: 1. Demographic and socio-economic characteristics of households at respondents $(\mathrm{n}=253)$

\begin{tabular}{|c|c|c|c|c|c|}
\hline Household Characteristics & $\mathrm{n}$ & $\%$ & Household Characteristics & $\mathrm{n}$ & $\%$ \\
\hline Sex & & & \multicolumn{3}{|l|}{ Type of respondents } \\
\hline Male & 174 & 68.8 & Carpenters & 123 & 48.6 \\
\hline Female & 79 & 31.2 & Other wood processors & 74 & 29.2 \\
\hline Age & & & Non wood processors & 56 & 22.1 \\
\hline$<18$ & 01 & 0.4 & \multicolumn{3}{|l|}{ Marital status } \\
\hline $18-30$ & 134 & 53.0 & Married & 159 & 62.8 \\
\hline $31-50$ & 98 & 38.7 & Single & 76 & 30.0 \\
\hline $51-70$ & 14 & 05.5 & Separated & 13 & 05.1 \\
\hline$>71$ & 06 & 02.4 & Divorced & 05 & 02.0 \\
\hline Educational background & & & Residence at Nabitende to & wnshi & \\
\hline No formal education & 11 & 04.3 & Bukose ward & 83 & 32.8 \\
\hline Elementary education & 09 & 03.6 & Bulisa ward & 44 & 17.4 \\
\hline Primary education & 69 & 27.3 & Buyale ward & 71 & 28.1 \\
\hline Secondary education & 120 & 47.4 & Out side the township & 55 & 21.7 \\
\hline Tertiary education & 44 & 17.4 & \multicolumn{3}{|c|}{ Experience on activities at Nabitende township } \\
\hline Family size(Dependants) & & & $1-5$ & 60 & $23.7^{*}$ \\
\hline 0 & 25 & 09.9 & $6-10$ & 80 & 31.6 \\
\hline $1-5$ & 123 & 48.6 & $11-15$ & 27 & 10.7 \\
\hline $6-10$ & 64 & 25.3 & $16-20$ & 23 & 09.1 \\
\hline $11-15$ & 18 & 07.1 & $>21$ & 63 & 24.9 \\
\hline$>16$ & 23 & 09.1 & & & \\
\hline
\end{tabular}

Source: Researcher's field data 2014

Table 1 show that wood exploitation is male dominated (68.8\%) given the masculine nature of the associated jobs such as carpentry. This equally justifies the youthfulness of the participants mainly falling within (18-50)years bracket at $91.7 \%$. It was also evident that $95.7 \%$ of the respondents had formal education thus were aware of their actions both literary and in any other means. The dependency syndrome (90.1\%) apparently was a push towards exploitation of resource to the proximity of the affected (Simons, 1981). The same was also reflected in the marital status of the respondents (67.9\%) married and separated. All the respondents had some experience on activities carried at Nabitende Township, a collecting centre for forest wood products in eastern Uganda.

\section{Factors favouring woody forest resources exploitation at Nabitende Township, Eastern Uganda}

This was the aspect of the first objective which was sub-divided into three viz. wood works and associated activities, factors favouring woody forest resources exploitation, and a correlation of perception of wood and non-wood processors on factors favouring woody forest resources exploitation at Nabitende Township. Table 2 shows a collective response of both wood and non-wood processors.

Table: 2 Wood works and associated activities at Nabitende township, Eastern Uganda $(n=253)$

\begin{tabular}{lcc}
\hline Activity & $\mathrm{n}$ & $\%$ \\
\hline Furniture making/ fabrication & 190 & 75.1 \\
Timber extraction & 150 & 59.3 \\
Moulding timber & 72 & 28.5 \\
Furniture selling & 62 & 24.5 \\
Electric saw milling & 59 & 23.3 \\
Timber selling & 47 & 18.6 \\
Timber transporting & 40 & 15.8 \\
\hline
\end{tabular}

Source: Researcher's field data 2014

Furniture fabrication was the dominant activity in woody forest resource exploitation (75.1\%) especially in the making of household furniture (Table: 2).This could have started in the early 1950s with the establishment of a saw mill in the area. The furniture making was also supported by furniture market in the area, electric machines such as saw mills and timber moulding machines as per Table: 2 .The saw mill was a reflector 
the thriving wood processing industry the country underwent before the expulsion of the Asians. Since then pit sawing has taken centre stage in converting round wood into sawn wood (NEMA, 1996).

Timberextraction was also a major activity manifested by more than half the responses $(59.3 \%)$. This could be backed by both timber selling and timber transporting as activities (Table: 2). Through observation timber was transported to the township using lorries of varying tonnages ranging from four to two tones, besides carts and bicycles depending on the distance from the source. The timber was transported basically using either bicycles or carts within the town. This therefore acted as a testimony of the town's being a collecting centre for timber in the region.

The perceptions of both wood and non-wood processors on factors favouring the woody forest resources exploitation at Nabitende township as in Table:3 below:-

Table: 3.Factors favouring the woody forest resources exploitation at Nabitende township Eastern Uganda

\begin{tabular}{|c|c|c|c|c|c|c|}
\hline Factors & $\begin{array}{l}\text { Woo } \\
\text { perc }\end{array}$ & $\begin{array}{l}\text { processors' } \\
\mathrm{n}=197)\end{array}$ & $\begin{array}{l}\text { Nor } \\
\text { per }\end{array}$ & $\mathrm{n}=56)^{\text {processors }}$ & $\begin{array}{l}\text { General } \\
(\mathrm{n}=253)\end{array}$ & perception \\
\hline Wood processing skills & 171 & $(86.8 \%)$ & 45 & $(80.4 \%)$ & 217 & $(85.8 \%)$ \\
\hline Access to hydroelectricity & 163 & $(82.7 \%)$ & 42 & $(75.0 \%)$ & 205 & $(81.0 \%)$ \\
\hline Accessibility to raw materials & 108 & $(54.8 \%)$ & 24 & $(42.9 \%)$ & 132 & $(52.2 \%)$ \\
\hline Historical accident & 147 & $(74.6 \%)$ & 44 & $(78.6 \%)$ & 181 & $(71.5 \%)$ \\
\hline Agglomeration & 149 & $(75.6 \%)$ & 46 & $(82.1 \%)$ & 195 & $(77.1 \%)$ \\
\hline Accessibility to muvule timber & 145 & $(73.6 \%)$ & 36 & $(64.3 \%)$ & 181 & $(71.5 \%)$ \\
\hline Capital & 154 & $(78.2 \%)$ & 35 & $(62.5 \%)$ & 189 & $(74.7 \%)$ \\
\hline Accessibility to market & 168 & $(85.3 \%)$ & 40 & $(71.4 \%)$ & 208 & $(82.2 \%)$ \\
\hline Wood processing machines & 163 & $(82.7 \%)$ & 48 & $(85.7 \%)$ & 211 & $(83.4 \%)$ \\
\hline Cheap semi-skilled labour & 134 & $(68.0 \%)$ & 48 & $(85.7 \%)$ & 182 & $(71.9 \%)$ \\
\hline Entrepreneurial skills & 138 & $(70.1 \%)$ & 44 & $(78.6 \%)$ & 182 & $(71.9 \%)$ \\
\hline
\end{tabular}

Source: Researcher's field data 2014

More than three quarters $(85.8 \%)$ of the respondent agreed that the possession of wood processing skills was a cardinal factor into the existence of wood works and associated activities. Through observations the following skills were evident; carpentry and joinery, pitsawying and operation of wood processing machineries such as; power saws, locally assembled electricity driven machines for instance table/circular saws, wood lathe and two planner thicknessers. Close to this artisan skills were both entrepreneurial skills (71.9\%) and cheap labour $(71.9 \%)$. Apparently, all carpenters produced a universal design which was very wood intensive either making components or complete items depending on the market. The results were therefore in concomitant to many authors who venerated artisan skills on these types of activities (Alexander \& Gibson,1979; Leong \& Morgan, 1994; Getis et al,2008).

Wood processing machineries was a second factor into the existence of these activities at $83.4 \%$. From interviews it was clear this had a bearing on the historical accident whereBernard established a saw mill in the area in 1949. Though could also be viewed as a chance factor, the proprietor had shifted this saw mill from many sites in Busoga region before settling to Nabitende viz. Idudi, Butaba, Bugweri county and Nakivumbi and Isegero, Busiki county the two areas not currently comparable to Nabitende (Waugh,1995). This became a spring board on which the whole wood working activities in this area based acknowledged by $71.5 \%$. The machines form part of the capital on which these activities depend on, though capital was acknowledged by $74.7 \%$.The respondents' perceptions could have been influenced by soft loans provided by village micro-finance currently present in the township. Besides this the timber traders came in with their own cash requiring only appropriate entrepreneurial skills to manage the enterprise.This added to the availability of market perceived by $82.2 \%$ of the respondents. Thus observably, no timber product could fail to be marketed from within Nabitende Township.

The results attested to Weber's agglomeration economics where firms enjoyed the benefit of cheap semi-skilled labour in cheap rental environment(Getis et al,2008). This was testified by $77.1 \%$ of the respondents. Besides labour, three phase hydroelectricity was also available and accessible to these entrepreneurs acknowledged by $81 \%$. Unfortunately electricity was not a determinant factor for Bernard for he used steam to run his saw mill basing on abundant fuel wood then. To him as per the interviews accessibility to both raw materials and export routes were comparatively cardinal. The accessibility issue elicited slightly more than a half the respondents' perception (52.2\%). This could be attributed to the poor status of the weathered roads in the rural areas especially during the rainy seasons. Despite the challenges of accessibility the aspect of muvule timber as a major factor was acknowledged by more than two thirds of the respondents $(71.5 \%)$. Correlations of the perceptions of both wood and non-wood processors on the given factors are as in Table 4. 
Table: 4: A correlation analysis of the perceptions of wood and non-wood processors on factors favouring woody forest resources exploitation at Nabitende township, Eastern Uganda $(\mathrm{n}=253)$

\begin{tabular}{|c|c|c|c|c|c|c|c|c|}
\hline \multirow[t]{2}{*}{$\mathrm{N}^{0}$} & \multicolumn{3}{|c|}{ Wood processors' perceptions $(n=197)$} & \multicolumn{3}{|c|}{ Non-wood processors' perceptions $(\mathrm{n}=56)$} & \multirow[t]{2}{*}{$\mathrm{d}$} & \multirow[t]{2}{*}{$d^{2}$} \\
\hline & Factors & & Rank & Factors & & Rank & & \\
\hline 1 & Wood processing skills1 & 71 & 1 & Wood processing skills & 45 & 4 & -3 & 9 \\
\hline 2 & Access to hydroelectricity & 163 & 3.5 & Access to hydroelectricity & 42 & 7 & -3.5 & 12.25 \\
\hline 3 & Accessibility to raw materials & 108 & 11 & Accessibility to raw materials & s 24 & 11 & 0 & 0 \\
\hline 4 & Historical accident & 147 & 7 & Historical accident & 44 & 5.5 & 2.5 & 6.25 \\
\hline 5 & Agglomeration & 149 & 6 & Agglomeration & 46 & 3 & 3 & 9 \\
\hline 6 & Access to muvule timber & 145 & 8 & Access to muvule timber & 36 & 9 & -1 & 1 \\
\hline 7 & Capital & 154 & 5 & Capital & 35 & 10 & -5 & 25 \\
\hline 8 & Accessibility to market & 168 & 2 & Accessibility to market & 40 & 8 & -6 & 36 \\
\hline 9 & Wood processing machines & 163 & 3.5 & Wood processing machines & 48 & 1.5 & 2 & 4 \\
\hline 10 & Cheap semi-skilled labour & 134 & 10 & Cheap semi-skilled labour & 48 & 1.5 & 8.5 & 72.25 \\
\hline 11 & Entrepreneurial skills & 138 & 9 & Entrepreneurial skills & 44 & 5.5 & 3.5 & 12.25 \\
\hline
\end{tabular}

Source: Researcher's field data $2014 \Sigma \mathrm{d}^{2} 187$

Table 4 through tabulations shows that $\mathrm{r}=0.25$. This value lay on a $(<0.35)$ segment of the strength of a correlation, manifesting a slight correlation, at a 0.05 level of significance (Fowler et al, 1998; Mugenda \& Mugenda, 2003 and Fraenkel \& Wallen, 2008). It could therefore, be concluded, that there was a slight relationship between the perceptions of wood and non-wood processors on factors favouring woody forest resources exploitation at Nabitende township, Eastern Uganda.

\section{Woody forest resources used at Nabitende Township, Eastern Uganda}

This was the second specific objective of the study on which the researchers sub-divided into the following aspects; preferred timber species, sources of timber and significant markets for woody forest products processed from Nabitende Township. Preferred timber species used at Nabitende Township are presented in Table 5.

Table: 5: Preferred timber species used at Nabitende township, Eastern Uganda $(\mathrm{n}=253)$

\begin{tabular}{|c|c|c|c|c|}
\hline \multicolumn{2}{|c|}{ Timber species } & \multicolumn{3}{|c|}{ Level of preference } \\
\hline Local name & Botanical name & Much & Undecided & Not much \\
\hline Muvule & Milicia excelca & $218(86.2 \%)$ & $11(04.4 \%)$ & $24(09.5 \%)$ \\
\hline Mukoko & Ficus platyphylla & $190(75.1 \%)$ & $23(09.1 \%)$ & $40(15.8 \%)$ \\
\hline Muyembe & Mangifera indica & $131(51.8 \%)$ & $65(25.7 \%)$ & $57(22.5 \%)$ \\
\hline Fenhe & Artocapus heterophylus & $151(59.7 \%)$ & $59(23.3 \%)$ & $43(17.0 \%)$ \\
\hline Mukunyu & Ficus sur & $193(76.3 \%)$ & $30(11.9 \%)$ & $30(11.9 \%)$ \\
\hline Kilitunsi & Eucalyptus grandis & $199(78.7 \%)$ & $30(11.9 \%)$ & $24(09.5 \%)$ \\
\hline Musizi & Maesopsis eminii & $218(86.2 \%)$ & $15(05.9 \%)$ & $20(07.9 \%)$ \\
\hline Musita & Alizia coriaria & $203(80.2 \%)$ & $22(08.7 \%)$ & $28(11.1 \%)$ \\
\hline Kabalira & Ficus mucuso & $191(75.5 \%)$ & $26(10.3 \%)$ & $36(14.2 \%)$ \\
\hline Mugaire & Piliostigma thonningii & $185(73.1 \%)$ & $32(12.6 \%)$ & $36(14.2 \%)$ \\
\hline Muziru & Pseudosndias microcarps & $180(71.1 \%)$ & $36(14.2 \%)$ & $37(14.6 \%)$ \\
\hline Musambya & Markhamia lutea & $200(79.1 \%)$ & $25(09.9 \%)$ & $28(11.1 \%)$ \\
\hline Nongo & Albizia grandibracteata & $174(68.8 \%)$ & $32(12.6 \%)$ & $47(18.6 \%)$ \\
\hline
\end{tabular}

Source: Researcher's field data 2014

The results show that Milicia excelca and Maesopsis eminii had equal high preference amongst the respondents at $86.2 \%$ (Table: 5). Maesopsis eminii's high preference contradicted both observation and interviews from the carpenters who preferred Alizia coriaria to it besides Milicia excelca. It was clear that Maesopsis eminii was used mainly in the construction for its light and cheap. Interview results had it that Milicia excelca was the most highly demanded in the furniture industry for its being easy to work on, attractive and visibly a hard wood. The strength of timber in this case lacked standardization for it was either though visual appearance or known local history of a tree species in concomitant to Zziwa et al (2009).

Table 5 also shows that non-traditional timber tree species such as fruit trees were also utilised as; Artocapus heterophylus (59\%) and Mangifera indica (51.8\%) besides the decimal acceptance of utilization of Piliostigma thonningii traditionally used as a back cloth and cover to the dead as per the interview and observation. This showed the intensity of forest wood products exploitation in Eastern Uganda to serve the demands of the ever increasing urban population countrywide which stands at a growth rate of 5.7\% (MFPED 2008 cited by NEMA,2008). The sources of timber used at Nabitende Township are portrayed in Table 6. 
Table:6: Sources of timber used at Nabitende township, Eastern Uganda $(n=253)$

\begin{tabular}{lcc}
\hline Source of timber & $\mathrm{n}$ & $\%$ \\
\hline Kaliro district & 205 & $(81.0 \%)$ \\
Namutumba district & 198 & $(78.3 \%)$ \\
Butaleja district & 174 & $(68.8 \%)$ \\
Luuka district & 195 & $(77.1 \%)$ \\
Buyende district & 202 & $(79.8 \%)$ \\
Kamuli district & 186 & $(73.5 \%)$ \\
Nambaale sub-county & 178 & $(70.4 \%)$ \\
Namungalwe sub-county & 158 & $(60.5 \%)$ \\
Nawandala sub-county & 200 & $(79.1 \%)$ \\
Nabitende sub-county & 188 & $(74.3 \%)$ \\
Bugiri districtl & 29 & $(51.0 \%)$ \\
\hline
\end{tabular}

Source: researcher's field data 2014

Table 6 shows that Kaliro district was the main supplier of timber (81\%) followed by Namutumba (78.3\%) with Bugiri district being the least (51\%) given its distance from the township. The leading sub-county in the neighbourhood of Nabitende township was Nawandala (79\%) and least was Namungalwe $(60.5 \%)$ ostensibly attributed to its proximity to Iganga Municipal council. The timber from these areas could observably be transported on lorries, motor cycles, pick ups, carts and bicycles depending on the capital, distance where the timber was sourced, amount/size of timber and accessibility of the source.

The results showed that timber was mainly illegally exploited for there was only one registered pit sawyer, Iganga Pit sawyers and Furniture Mart operating on public land in Iganga by then according to the records at district forest office. The 1995 Constitution of Uganda made it hard for District Forest Officers to manage trees on public land for it clearly stipulates that land is individually owned by the citizens (The Republic of Uganda, 1995). The same constitution in parts advocates for the promotion of environmental awareness which takes on both public and government forest reserves. Thus the dominance of the former aspect was a truncation of the constitution. A chi square statistic value of the residents' view on market for the processed woody forest products is presented on Table. 7 .

Table.7. Summary of chi square statistic value of the residents' views on market for wood products from Nabitende township $(\mathrm{n}=253)$

\begin{tabular}{l|l|l|l|l}
\hline \multirow{2}{*}{ Market } & \multicolumn{3}{c}{ Residents' views } & \multicolumn{1}{c}{} \\
\cline { 2 - 5 } & Observed & Expected & $\chi^{2}$ calculated & $\chi^{2}$ Tabulated \\
\hline Iganga town & 232 & 253 & 1.7 & 9.21 \\
Kaliro town & 200 & 253 & 11.1 & 9.21 \\
Kamuli town & 191 & 253 & 15.2 & 9.21 \\
Busia town & 230 & 253 & 2.1 & 9.21 \\
Malaba town & 217 & 253 & 5.1 & 9.21 \\
Kampala city & 227 & 253 & 2.7 & 9.21 \\
Mukono town & 200 & 253 & 11.1 & 9.21 \\
Kumi town & 225 & 253 & 3.1 & 9.21 \\
Mbale town & 229 & 253 & 2.3 & 9.21 \\
Juba city & 221 & 253 & 4.0 & 9.21 \\
Tororo town & 199 & 253 & 11.5 & 9.21 \\
Jinja town & 206 & 253 & 8.7 & 9.21 \\
Nambaale sub-county & 177 & 253 & 22.8 & 9.21 \\
\hline
\end{tabular}

Notes: $\mathrm{d} f=2$ at $0.01=9.210$

Source: Researcher's Field data 2014

Table.7.shows that Iganga town was the most significant market for wood products from Nabitende township at $\left(\chi^{2}=1.7<9.21\right.$ at $\left.\mathrm{df}=2\right)$ compared to other markets. This could be attributed to the place being a collecting centre in Eastern Uganda. Other very significant markets were Busia,Mbale,Kampala city, Kumi, Juba city, Malaba and Jinja town all at $\left(\chi^{2}<9.21\right.$ at $\left.\mathrm{df}=2\right)($ Table.7). From table 4 the products were accessing Kenyan market through Busia and Malaba; while South Sudan had a direct link to the capital city, Juba. Ironically, Nambaale sub-county where Nabitende township was locate had the worst market at $\left(\chi^{2}=22.8>9.21\right.$ at $\mathrm{df}=2)$. Other poor markets included Kaliro,Tororo, and Kamuli all at $\left(\chi^{2}>9.21\right.$ at $\left.\mathrm{df}=2\right)($ Table.7).

An assessment of the contribution of woody forest product exploitation on the transformation of Nabitende village into a township in Eastern Uganda

The perception of Nabitende Township residents viz. carpenters, other wood processors and non-wood processors, on how woody forest resources exploitation has transformed the then rural Nabitende into a township is presented on Table 8 . 
Woody forest products utilization and rural area transformation in Eastern Uganda: A case...

Table:8: Households' perception on transformation of the once rural area into Nabitende township, Eastern Uganda $(n=253)$

\begin{tabular}{l|l|l|l|l|}
\hline Aspect & Perceptions & \multicolumn{2}{l}{$\begin{array}{l}\text { Total } \\
(\mathrm{n}=253)\end{array}$} \\
\cline { 2 - 4 } & $\begin{array}{l}\text { Carpenters } \\
(\mathrm{n}=123)\end{array}$ & $\begin{array}{l}\text { Other } \begin{array}{c}\text { wood } \\
\text { processors }(\mathrm{n}=74)\end{array} \\
\text { Influx of population }\end{array}$ & $\begin{array}{l}\text { Non-wood } \\
\text { processors } \\
(\mathrm{n}=56)\end{array}$ & \\
Market for agricultural produce & $103(83.7 \%)$ & $61(82.4 \%)$ & $48(85.7 \%)$ & $212(83.8 \%)$ \\
Government services established & $103(83.7 \%)$ & $59(79.7 \%)$ & $26(46.4 \%)$ & $188(74.3 \%)$ \\
Confortable housing units constructed & $95(77.2 \%)$ & $53(71.6 \%)$ & $32(57.1 \%)$ & $180(71.1 \%)$ \\
Small scale industries established & $101(82.1 \%)$ & $63(85.1 \%)$ & $13(23.2 \%)$ & $177(69.9 \%)$ \\
Employment & $110(89.4 \%)$ & $62(83.8 \%)$ & $47(83.9 \%)$ & $219(86.6 \%)$ \\
Electricity & $99(80.5 \%)$ & $55(74.3 \%)$ & $42(75.0 \%)$ & $196(77.5 \%)$ \\
Establishment of private schools & $104(84.6 \%)$ & $67(90.5 \%)$ & $22(39.3 \%)$ & $193(76.3 \%)$ \\
Establishment of leisure places & $109(88.6 \%)$ & $61(82.4 \%)$ & $17(30.4 \%)$ & $187(73.9 \%)$ \\
Prostitution & $104(84.6 \%)$ & $62(83.8 \%)$ & $42(75.0 \%)$ & $208(82.2 \%)$ \\
High rents & $89(72.4 \%)$ & $50(67.6 \%)$ & $49(87.5 \%)$ & $188(74.3 \%)$ \\
Micro-finance/e-banking services available & $106(86.2 \%)$ & $62(83.8 \%)$ & $45(80.4 \%)$ & $213(84.2 \%)$ \\
Churches established & $102(82.9 \%)$ & $56(75.7 \%)$ & $49(87.5 \%)$ & $207(81.8 \%)$ \\
\hline
\end{tabular}

Source: Researcher's field data 2014

More than three quarters of the households agreed on the following aspects on transformation of the then Nabitende village according to table 8(establishment of Small scale industries (86.6\%); High rents (84.2\%);population influx (83.8\%); establishment of churches(83.4\%); establishment of leisure places(82.2\%); availability of micro-finance services(81.8\%); employment(77.5\%); and electricity (76.3\%).Through observation various small scale industries had been established viz. posho mills, timber processing machines, metal fabricators, rice processing and coffee processing mills besides carpentry workshops. These could have got a trickling down effect on attracting the population for casual employment,churches, entertainment joints, and micro-finance services (Table.8). The attracted population has made the rural area cosmopolitan as it were in the colonial times when this region attracted outsiders for casual jobs (NEMA, 1994).

Influx of population came in with the following; market for agricultural produce within the proximity of peasants in the neighbourhood of Nabitende township (74.3\%);negatively prostitution was also cropping in as business $(74.3 \%)$; many observable private schools were established to supplement government primary schools with two private secondary schools (73.9\%); apparently there was no government aided secondary school within a four kilometre reach of the township; government services such as; boreholes, primary schools, and a central police station was established to serve the population acknowledged by $71.1 \%$ of the respondents and fair housing units compared to the village huts were established agreed by $69.9 \%$ of the respondents (Table. 8 ). Thus a transformation in the rural landscape where Nabitende township was established in Eastern Uganda. Correlation analysis of the given perceptions is presented on Table 9.

Table.9: A Spearman rank correlation analysis of the perceptions of wood and non-wood processors on contribution of exploitation of forest wood products on transformation of Nabitende township, Eastern Uganda

\begin{tabular}{|c|c|c|c|c|c|c|c|}
\hline \multirow{3}{*}{$\mathrm{N}^{0}$} & \multirow[t]{3}{*}{ Aspect } & \multicolumn{4}{|c|}{ Perception of the households } & \multirow[t]{3}{*}{ d } & \multirow{3}{*}{$d^{2}$} \\
\hline & & \multicolumn{2}{|c|}{ Wood processors(n=197) } & \multicolumn{2}{|c|}{ Non-wood processors $(\mathrm{n}=56)$} & & \\
\hline & & & Rank & & Rank & & \\
\hline 1 & Influx of population & 164 & 7.5 & 48 & 3 & 4.5 & 20.25 \\
\hline 2 & Market for agricultural produce & 162 & 9 & 26 & 10 & -1 & 1 \\
\hline 3 & Government services established & 148 & 12 & 32 & 9 & 3 & 9 \\
\hline 4 & Confortable housing units constructed & 164 & 7.5 & 13 & 13 & -5.5 & 30.25 \\
\hline 5 & Small scale industries established & 172 & 1 & 47 & 4 & -3 & 9 \\
\hline 6 & Employment & 154 & 11 & 42 & 7.5 & 3.4 & 11.56 \\
\hline 7 & Electricity & 171 & 2 & 22 & 11 & -9 & 81 \\
\hline 8 & Establishment of private schools & 170 & 3 & 17 & 12 & -9 & 81 \\
\hline 9 & Establishment of leisure places & 166 & 5.5 & 42 & 7.5 & -2 & 4 \\
\hline 10 & Prostitution & 139 & 13 & 49 & 1.5 & 11.5 & 132.25 \\
\hline 11 & High rents & 168 & 4 & 45 & 5.5 & -1.5 & 2.25 \\
\hline 12 & Micro-finance/e-banking services available & 158 & 10 & 49 & 1.5 & 8.5 & 72.25 \\
\hline 13 & Churches established & 166 & 5.5 & 45 & 5.5 & 0 & 0 \\
\hline
\end{tabular}

Source: Researcher's Field Date $2014 \sum \mathrm{d} 2=453.81$

Table. 9 shows a weak negative association at $\mathrm{r}^{2}=-0.25$ of the perceptions of both wood and non-wood processors for it lies within $(<0.35)$ strength of correlation (Fowler et al, 2001). It was also observable that the high rankings on perceptions on either sidewent with the low scores except on establishment of churches at Nabitende Township. This was in line with Aron et al (2009)'s perception on negative linear correlations. 
Despite the statistically negative correlation interviews and observation agree on the fact that forest wood products exploitation has transformed the hither to rural environment.

\section{Conclusion And Recommendations}

Furniture works and timber extractions especially pit sawing were the main woody forest resources exploitation activities at Nabitende Township. These were mainly favoured by artisan skills, establishment of wood processing machines and access to market for the products. Iganga, Busia and Mbale towns were the most significant markets for activities while Kaliro and Namutumba districts besides Nawandala sub-county were where the timber was sourced especially Milicia excelca, Maesopsis eminii and Alizia coriaria. The transformation of the then rural area could be seen by the existence of small scale industries in the area such as wood processing machines, agro-based processing industries and metal fabrication machines; population increase and consequent house rent hikes in the rural setting. The functions and the pull factors such as employment opportunities, social amenities, and security besides the change of village scenery into a concentration of artisan workshops and houses was an indicative transformation attributed to woody forest resources exploitation at Nabitende Township, Eastern Uganda.

It was therefore in the view of researchers that there was need to sensitize the artisans on the sustainable utilization of the forest resources used by the forest and environment officers. It was observed that the exploitation was higher than regeneration of the resources used given the market and the teething of locally constructed table/circular saws which were wasteful. The transformation was also deterrent to education of school going children who could provide child labour in the many activities the township. Early marriages were also rampant besides the many video showing centres within Nabitende Township. This then calls for strengthen of national laws to counteract these in addition to making bye-laws to control both child labour, operations of video shows and early marriages in the area. Thus through education the transformation could be sustained by the indigenous Nabitende residents.

\section{Acknowledgment}

The researcher is indebted in the contribution of the following towards the success of this research; Magumba, Richard, Livingstone Magumba, Magala Richard, Kagwa Livingstone- carpenters at Nabitende Township and Tigastiwa, David a research assistant a bonifide resident of the area.

\section{References}

[1]. Alexander, J.W., and Gibson, L.J. 1979. Economic Geography $2^{\text {nd }}$ ed. New Jersey: Prentice- Hall, Inc.

[2]. Amin, E.M. 2005. Social Science Research: Conception, Methodology and Analysis.Kampala:Makerere University.

[3]. Aron, A., Aron, E.N., and Coups, E. J. (2009). Statistics for psychology. $5^{\text {th }}$ Ed. New Jersey Pearson Prentice Hall.

[4]. Bailey, C.A. 2007. A Guide to Qualitative Field Research. ( $2^{\text {nd }}$ Ed). London: Pine Forge Press.

[5]. Bell, J. 1999. How to complete your Research Project successfully. New Delhi: UBS Publishers'Distributors Ltd.

[6]. Cauvery, R., Nayak, U.K.S, Girija, M. \& Meenakshi, R. 2007. Research Methodology. New Delhi: S.Chand\& Company Ltd.

[7]. De Blij, H.J ed (1988). Earth'88 changing geographic perception. Washington D.C National Geographic Society.

[8]. D'Silva,E., and Appanah (1993). Forestry management for sustainable development.Washington D.C: TheWorld Bank.

[9]. Fisher, C. 2007. Researching and writing a Dissertation: A guide for Business Students ( ${ }^{\text {nd }}$ Ed).Harlow: Prentice Hall-Financial Times.

[10]. Fowler, J., Cohen, L. and Jarvis, P. 1998. Practical Statistics for field Biology $2^{\text {nd }}$ ed. New York: John Wiley \& Sons.

[11]. Fraenkel, J.R \& Wallen, N.E. 2008. How to design and evaluate research in education. Boston: McGraw-Hill Higher Education

[12]. Gachanja, M. 2000. "View of an assessment report on degradation of Eburu Bahati Forest" Forest Action News Vol. 1 NNo. 1. Nairobi: Forest Action News Network. pp 5.

[13]. Gay, L.R., Mills, G.E \& Airasian, P. 2009. Educational Research: Competencies for Analysis and Applications. (9 ${ }^{\text {th }}$ Ed) New Jersey: Pearson Education International.

[14]. Getis, A., Getis,G. and Fellman, J.D. 2008. Introduction to Geography $12^{\text {th }}$ ed. Boston:McGrow Hill

[15]. http.// www.fao.org/DOCREP/005/Y4137E/y4137e07b.htm\#P865-120559 (Accessed 28 ${ }^{\text {th }}$ July, 2007).

[16]. Iganga District Farmers Association (IDFA). Iganga District, Uganda. (Accessed $5^{\text {th }}$ May, 2013).

[17]. Leong, G.C., and Morgan, G.C. 1994. Human and Economic Geography. New York: Oxford University Press.

[18]. Morse, J.M. \& Richards, L. 2002.Read me first for a user's guide to qualitative methods. New Delhi: Sage Publications.

[19]. Mugenda,O.M. \& Mugenda,A.G. 2003.Research Methods: Quantitative \&Qualitative Approaches. Nairobi: African Centre for Technology Studies (ACTS)

[20]. Nachmias, D. \& Nachmias,C. 1987.Research Methods in the Social Sciences ( $3^{\text {rd }}$ Ed). New York: St. Martin's Press.

[21]. NEMA 1994. State of Environment Report for Uganda 2000/2001.Kampala:Author.

[22]. NEMA 1996.State of Environment Report for Uganda 1996. Kampala: Author.

[23]. NEMA 2001. State of Environment Report for Uganda 2000/2001.Kampala:Author.

[24]. NEMA 2008. State of Environment Report for Uganda 2000/2001.Kampala:Author

[25]. NFA 2005. Guidelines for successful communication at the National Forestry Authority. Kampala: Author

[26]. Obua,J., Agea, J.G and Ogwal, J.J. 2010. Status of forests in Uganda. African Journal of Ecology. 48:853-859. Doi: 10.1111/j 1362028.2010.01217x Odokonyero, G.G.O. 2005.Pitsawn timber production in natural forests of Uganda. Rome: Food and Agriculture Organisation of the United Nations

[27]. Otieno, A.C. and Buyinza, M. 2010. Collaborative Forest Management in Uganda. A Strategy for controlling deforestation in West Bugwe Forest Reserve, Busia District. Research Journal of Applied Sciences 5(5). Medwell Journals pp. $337-344$.

[28]. Republic of Uganda 2002, October.The National Forest Plan: Final Version. Kampala: Ministry ofWater,Lands and Environment. 
[29]. Simon,I.G.(1981).The ecology of natural resources. London: Edward Arnold.

[30]. The Republic of Uganda 1995. Constitution of the Republic of Uganda. Kampala: Uganda Printing and Publishing Corporation.

[31]. The Republic of Uganda (2003). The National Forestry and Tree Planting Act. The Uganda Gazette No. 37Volume XCVI date $8^{\text {th }}$ August, 2003. Entebbe: UPPC Entebbe by Order of the Government.

[32]. Waugh, D. 1995. Geography: An Integrated Approach. London: Nelson.

[33]. Whitmore, T.C and Sayer, J.A. ed1994. Tropical deforestation and species extinction. London: Chapman \& Hall

[34]. Zziwa, A., Ziraba, Y.N., and Mwakali, J.A. 2009. Timber use practices in Uganda's building Constructionindustry: Current situation and future prospects. The Journal of the Institute of Wood Science Vol.19. The Wood Technology Society of the Institute of Materials and Mining pgs 48-53 